(c) Group of authors, 2019

UDC 615.015 .5

DOI - https://doi.org/10.14300/mnnc.2019.14132

ISSN - 2073-8137

\title{
CHANGES IN THE SEVERITY OF HALOPERIDOL CATALEPSY IN RATS UNDER CHRONIC ADMINISTRATION OF NEUROLEPTICS
}

\author{
Baturina M. V., Beier E. V., Boev O. I., Popov A. V.
}

Stavropol State Medical University, Stavropol, Russian Federation

\section{ИЗМЕНЕНИЕ ВЫРАЖЕННОСТИ ГА^ОПЕРИАОАОВОЙ КАТААЕПСИИ У КРЫС ПРИ ХРОНИЧЕСКОМ ВВЕАЕНИИ НЕЙРОАЕПТИКОВ}

\author{
М. В. Батурина, Э. В. Бейер, О. И. Боев, А. В. Попов \\ Ставропольский госуАарственный меАицинский университет, \\ Ставрополь, Российская Фелерация
}

In experiments on 80 laboratory rats, the change in the severity of catalepsy caused by the intraperitoneal administration of haloperidol at a dose of $2 \mathrm{mg} / \mathrm{kg}$ was assessed for chronic administration of antipsychotics to these animals (haloperidol 0.1 and $0.5 \mathrm{mg} / \mathrm{kg}$ and risperidone 0.1 and $0.5 \mathrm{mg} / \mathrm{kg}$ ). After 15 and 30 days of administration of antipsychotics, catalepsy in rats was less pronounced than in control animals (administration of saline).

Keywords: catalepsy, rats, antipsychotics, tolerance, haloperidol, risperidone

В опытах на 80 лабораторных крысах оценивали изменение выраженности каталепсии, вызванной внутрибрюшинным введением галоперидола в дозе 2 мг/кг при хроническом введении этим животным нейролептиков (галоперидол 0,1 и 0,5 мг/кг и рисперидон 0,1 и 0,5 мг/кг). Через 15 и 30 суток введения нейролептиков каталепсия у крыс была менее выраженной, чем у контрольных животных (введение физиологического раствора).

Ключевые слова: каталепсия, крысы, нейролептики, толерантность, галоперидол, рисперидон

For citation: Baturina M. V., Beier E. V., Boev O. I., Popov A. V. CHANGES IN THE SEVERITY OF HALOPERIDOL CATALEPSY IN RATS UNDER CHRONIC ADMINISTRATION OF NEUROLEPTICS. Medical News of North Caucasus. 2019;14(3):536537. DOI - https://doi.org/10.14300/mnnc.2019.14132

Для цитирования: Батурина М. В., Бейер Э. В., Боев О. И., ПопОв А. В. ИЗМЕНЕНИЕ ВЫРАЖЕННОСТИ ГАЛОПЕРИДОЛОВОЙ КАТАЛЕПСИИ У КРЫС ПРИ ХРОНИЧЕСКОМ ВВЕДЕНИИ НЕЙРОЛЕПТИКОВ. МеДИЦИНСКИЙ ВеСТНИК Северного Кавказа. 2019;14(3):536-537. DOI - https://doi.org/10.14300/mnnc.2019.14132

rolonged use of drugs often enough faced with the development of tolerance. Increasing doses of drugs are usually used to achieve a pharmacological effect. Tolerance is often formed during therapy with antipsychotic drugs in the clinic of mental illness [1-4]. It was important to develop an appropriate experimental model for studying the mechanisms of development of tolerance to antipsychotics.

The work aimed to study changes in the severity of haloperidol catalepsy in rats that were given the neuroleptics haloperidol and risperidone.

Material and Methods. The experiments were performed on 80 white non-linear rats males weighing 300-350 g. Animals divided into four groups of 15 animals each. Rats of the first group were chronically administered with haloperidol at a dose of $0.1 \mathrm{mg} / \mathrm{kg}$, of the second group, $0.5 \mathrm{mg} / \mathrm{kg}$. The animals of the third group were injected with risperidone $-0.1 \mathrm{mg} / \mathrm{kg}$, the fourth group $-0.5 \mathrm{mg} / \mathrm{kg}$. The drugs were administered intraperitoneally for 30 days. In those days, when the severity of haloperidol catalepsy was determined, neither antipsychotics nor saline were administered. Catalepsy was recorded on days 15 and 30 using antipsychotics. It served as a control group of rats (20 animals) to obtain the same amount of saline.
The cataleptogenic effect of haloperidol was recorded in the «lecturer's pose» test, which makes it possible to assess the ability of an animal to maintain an artificially attached position. The front paws of rats were placed on a horizontal bar located at the height of $10 \mathrm{~cm}$, the time of posture preservation in seconds was recorded, and the number of animals in the group holding the "lecturer's pose» for $60 \mathrm{~s}$ was determined. To obtain catalepsy, haloperidol was administered intraperitoneally at a dose of $2 \mathrm{mg} / \mathrm{kg}$. The severity of the cataleptogenic effect was assessed 60, 90, and 120 minutes after the injection of the drug.

The results were subjected to statistical processing using a software package Statistica 6.0 (StatSoft, USA). The studies were carried out following the Rules of Good Laboratory Practice of the Russian Federation (Order of the Ministry of Health of the Russian Federation № 199n dated 04/01/2016) and the guidelines of the «Guidelines for conducting preclinical studies of drugs. Part One»[2].

Results and Discussion. When evaluating the cataleptogenic effect of haloperidol 15 days after the chronic use of antipsychotics, a tendency to reduce the time of preservation of the "lecturer's pose» by rats was revealed in comparison with the control group of animals. These differences were noted already at the first test (after 60 minutes) and increased with subsequent determinations ( 90 and 120 minutes after the injection of 
a cataleptogenic dose of the drug). The most significant differences were found in the group of animals treated with haloperidol at a dose of $0.5 \mathrm{mg} / \mathrm{kg}$. In control, the average retention time in the "lecturer position" was $59.0 \pm 1.0 \mathrm{~s}$. In the group of rats treated with $0.5 \mathrm{mg} / \mathrm{kg}$ haloperidol, $45.6 \pm 4.2 \mathrm{~s}(\mathrm{p}<0.05)$.

When determining the proportion of animals retaining the given position for at least $60 \mathrm{~s}$, it was found that in the groups treated with antipsychotics, the number of such rats was significantly less than in control. In the group of rats injected with $0.5 \mathrm{mg} / \mathrm{kg}$ haloperidol, these animals were only $6.6 \%$ (the control group - $33.3 \%)(p<0.01)$. When tested after 120 minutes, they were half as much as in the control group (46.6\% and $90 \%$, respectively). A similar trend was observed with chronic use of risperidone. When testing 60 minutes after the introduction of a cataleptogenic dose of haloperidol, the number of rats that maintained a «lecturer's pose» of up to 60 s was $20 \%$ in the group receiving risperidone at a dose of $0.1 \mathrm{mg} /$ $\mathrm{kg}$, and in the group receiving $0.5 \mathrm{mg} / \mathrm{kg}-6.6 \%$. After $120 \mathrm{~min}$, the severity of catalepsy in the groups receiving risperidone was also less compared to the control.

The intensity of the cataleptogenic effect of haloperidol after a 30-day administration of antipsychotics was also lower than in control animals. The average duration of retention of the «lecturer's pose» in the first and second groups 90 minutes after the injection of the cataleptogenic dose of haloperidol was $37.2 \pm 4.4 \mathrm{~s}$ and $30.4 \pm 4.1 \mathrm{~s}$, respectively (in the control group $-48.8 \pm 4.6 \mathrm{~s}, \mathrm{p}<0.05$ ). In the third and fourth groups (risperidone 0.1 and $0.5 \mathrm{mg} /$ $\mathrm{kg}$ ), this indicator was $40.8 \pm 5.0 \mathrm{~s}$ and $38.2 \pm 5.2 \mathrm{~s}$.

When determining the number of animals that kept their pose for at least $60 \mathrm{~s}$, it was found that after chronic 30-day administration of haloperidol, the proportion of such rats in the first group was tested after 60 minutes $20 \%$, in the second $-6.6 \%$, in the third $-18.3 \%$, in the fourth $-16.6 \%$, in the control group - $33.3 \%$. When testing after 90 and 120 minutes, differences with the control group persisted. In the control group of animals, 120 minutes after the introduction of the cataleptogenic dose of haloperidol, the «lecturer's pose» remained $90 \%$ for $60 \mathrm{~s}$, in the first group $-73.3 \%$, in the second $-38.4 \%$, in the third $-73.3 \%$, in the fourth $-53.3 \%$. Moreover, in the group of animals receiving a high dose of haloperidol $(0.5 \mathrm{mg} / \mathrm{kg})$, a further weakening of the cataleptogenic effect was found.

Conclusions. Therefore, prolonged administration of low doses of haloperidol reduces the severity of haloperidol catalepsy. Risperidone, which has a slightly different mechanism of neurotropic action [3], also weakens catalepsy, although this effect was less pronounced than with the chronic use of haloperidol. Thus, the data obtained suggest that haloperidol catalepsy can be used to assess the formation of tolerance to neuroleptics.

\title{
Disclosures:
}

The authors declare no conflict of interest.

\section{References}

1. Arushanyan E. B., Psihofarmakologiya. V. 1. Stavropol, 2008.

2. Mironov A. N., Bunyatyan N. D., Vasilev A. N. Rukovodstvo po provedeniyu doklinicheskih issledovanij lekarstvennyh sredstv. Chast pervaya. Moscow: «Grif i K», 2012.

3. Chopko T. C., Lindsley C. W. Classics in Chemical Neuroscience: Risper-idone. ACS Chem. Neurosci. 2018;9(7):15201529. https://doi.org/10.1021/acschemneuro.8b00159

\section{About authors:}

Baturina Maria Vladimirovna, MD, PhD, Department of clinical pharmacology; tel.: +79064120387; e-mail: nimdark@mail.ru

Beier Eduard Vladimirovich, MD, PhD, Professor of the Department of pharmacology; tel.: +79624460500; e-mail: karokris@mail.ru

Boev Oleg Igorevich, MD, PhD, Head of the Department of psychiatry; tel.: +79283214202; e-mail: psycho@stgmu.ru

Popov Aleksey Viktorovich, MD, PhD, Professor of the Department of pharmacology; tel.: +78652354881; e-mail: popov_2003@bk.ru

(C) Group of authors, 2019

UDC 618.29-053.1-07

DOI - https://doi.org/10.14300/mnnc.2019.14133

ISSN - 2073-8137

\section{ULTRASOUND DIAGNOSTICS FOR FETAL AORTIC COARCTATION}

\author{
Dyuzhikov A. A., Duyzhikova A. V., Zhivova L. V., Likhachev-Mishchenko O. V.
}

Rostov Regional Clinical Hospital, Rostov-on-Don, Russian Federation

\section{УАЬТРАЗВУКОВАЯ АИАГНОСТИКА КОАРКТАЦИИ АОРТЫ У ПАОАА}

\author{
А. А. Аюжиков, А. В. Аюжикова, А. В. Живова, О. В. Аихачев-Мищенко \\ Ростовская областная клиническая больница, Ростов-на-Аону, Российская ФеАерация
}

The ultrasound assessment of the isolated coarctation of the aortic arch in the fetus was analyzed. Unfortunately, the features of the fetal blood circulation do not allow relying on the ultrasound criteria characteristics of a newborn because of the equal pressure in the ventricles of the fetal heart. This study provides ultrasound criteria for defects, which allows suspected pathologies to be verified in the fetus.

Keywords: aortic coarctation, fetus, prenatal ultrasound diagnosis, B-mode 